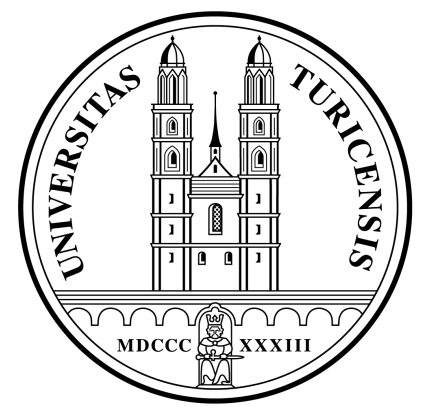

Institute for Strategy and Business Economics

University of Zurich

\author{
Working Paper Series
}

ISSN 1660-1157

Working Paper No. 138

Shared Ownership versus Third-Party Ownership

Stephan Nüesch, Egon Franck

November 2010 


\title{
Shared Ownership versus Third-Party Ownership
}

\author{
Stephan Nüesch, Egon Franck*
}

November 29, 2010

\begin{abstract}
Competitive advantage is based on a unique nexus of firm-specific investments that creates inimitable quasi-rents. Because of the impossibility of writing complete contracts, the distribution of the quasi-rents is vulnerable to opportunistic and inefficient behavior. This paper discusses two corporate governance models as institutional safeguards: shared ownership that assigns the rights of residual control to the firm-specific investors, and thirdparty ownership that assigns the rights of residual control to independent fiduciaries. Shared ownership entails higher costs of collective decision-making but lower agency costs than third-party ownership. The paper presents testable propositions, conditional on contextual factors, on which model is better able to incentivize firm-specific investments.
\end{abstract}

JEL-Classification: G30, G38, K22

Keywords: $\quad$ Corporate Governance, Firm-Specific Investments, Residual Rights of Control, Third-Party Ownership

\footnotetext{
* Stephan Nüesch, Senior Research and Teaching Associate, Institute of Strategy and Business Economics, University of Zurich, Plattenstrasse 14, CH-8032 Zürich, phone: +41 $44 \quad 63429$ 14, e-mail: stephan.nuesch@isu.uzh.ch (corresponding author); Egon Franck, Chair of Strategic Management and Business Policy, University of Zurich, Plattenstrasse 14, CH-8032 Zürich, phone: +41 4463428 45, e-mail: egon.franck@isu.uzh.ch.
} 


\section{INTRODUCTION}

Firms achieve competitive advantage by controlling valuable and rare resources that competitors can neither imitate nor substitute (e.g., Barney, 1991). A network of mutually specialized inputs is such a resource that creates economic rents that the market cannot replicate. In a simple case a corporation may have two groups of firm-specific investors: shareholders who provide the capital for buying firm-specific physical assets, and employees who have firm-specific knowledge of how to use these assets most effectively. The specific investments are complementary, being most productive when used together but losing much of their value when used separately. The firm-specific investments create quasi-rents, denoting the differences between the value of the investments in the firm and the value of their next-best use in another firm (Klein, Crawford, and Alchian, 1978). As writing complete, contingent contracts on how to distribute the quasi-rents is impossible, the cospecialization makes each party vulnerable to opportunistic and inefficient behavior by the other. To prevent any hold-up risk, both the shareholders and the employees may underinvest in firm-specific assets. As a result, the quasi-rents and the firm's competitive advantage decrease (Milgrom and Roberts, 1992).

In the spirit of Zingales (1998, p. 497), we define corporate governance as the complex set of constraints that shape the bargaining over the quasi-rents generated by the nexus of firm-specific investments. In particular, corporate governance determines the ownership structure of the firm. Ownership is a powerful tool, especially if contractual arrangements involve high transaction costs resulting from the specificities of the investments (Klein et al., 1978; Williamson, 1985). Building upon property rights theory (e.g., Grossman and Hart, 1988; Hart and Moore, 1990), we define ownership as endowment with the residual rights of control over an asset. These rights comprise "any decisions concerning the asset's use that are not explicitly controlled by law or assigned to another by contract" (Milgrom and Roberts, 1992, p. 289). The objective of the governance structure is to maximize the quasi-rents of the firm by providing optimal incentives for firm-specific investments. If only one party invests firm-specifically and thereby contributes to the firm's quasi-rents, this party should hold the residual rights of control in the firm. However, given a co-specialization of at least two parties, who should then have the residual rights of control so that the joint product of the nexus of specific investments is maximized?

This paper discusses two alternative answers to this question: one is to delegate the residual rights of control jointly to the firm-specific investors (shared ownership); the other to delegate the residual control rights to an independent third party that does not possess any 
firm-specific assets (third-party ownership). The shared ownership model recommends that all firm-specific investors either directly or through representation participate in deciding all matters not specifically regulated via contracts or the law (e.g., Furubotn, 1988; Blair, 1995; Franck, 2002; Osterloh and Frey, 2006). The purpose of this model is to increase the decision rights and bargaining power of those who contribute to the quasi-rents. The third-party ownership model suggests transferring the rights of residual control to independent third-party trustees who mediate between the conflicting interests of firm-specific investors but have no firm-specific assets themselves (Rajan and Zingales, 1998a; Blair and Stout, 1999; 2001; Luh Lan and Heracleous, 2010). While scholars have postulated either shared ownership or thirdparty ownership, none has yet analyzed under which circumstances one or the other governance structure is preferable. This paper contrasts the two governance models and explores the determinants of choosing one model over the other.

If different persons share the rights of residual control, they have to use some form of collective choice mechanisms for making decisions. When the interests of the decision makers diverge, collective choice mechanisms such as specific voting systems entail costs. In line with Hansmann (1996), we label these costs as costs of collective decision-making. We argue that shared ownership generally entails higher costs of collective decision-making than third-party ownership. If the decision-makers have their own firm-specific assets, they are more likely to engage in inefficient politics, power fights, and rent seeking than decisionmakers who have no firm-specific assets (Hansmann, 1996).

In most legal contexts - in particular in the U.S. - the board of directors ("board") enjoys ultimate control over the firm's assets and key strategic decisions (Blair and Stout, 2001). Once a decision is taken, the board delegates the implementation to professional managers. This delegation entails agency costs, defined as the costs of monitoring the managers and the costs of the managerial opportunism due to ineffective manager monitoring (Hansmann, 1996). In line with Murphy and Zàbojnik (2004, 2007), we consider the managerial capabilities and skills as transferable across corporations, or even industries. Thus managers do not belong to the group of firm-specific investors.

In the shared ownership model the firm-specific investors are represented on the board and directly supervise managers as their agents. In the third-party ownership model such direct supervision is not possible, the directors being independent outsiders. We argue that shared ownership results in lower agency costs because inside directors are familiar with internal processes and can, therefore, better monitor managers than independent outsiders. 
The overall preferability of one model over the other depends on the relative importance of the costs of collective decision-making and the agency costs. If the costs of collective decision-making are particularly high, the firm should install third-party ownership to facilitate the decision-making process. One of the main factors that increase decision-making costs is the diversity of the firm-specific investors. Shared ownership, in turn, has comparative cost advantages when monitoring the managers is difficult. Three factors that affect the agency costs are the complexity of the firm's organization, the knowledge intensity of the production process, and the growth rate of the industry.

The remainder of this paper is structured as follows. The next section explains why contracts fail in the presence of firm-specific investments and how corporate governance may mitigate the associated problems. Then, we describe the shared ownership model and the third-party ownership model. Subsequently, we analyze the relative suitability of the two models conditional on contextual factors and develop testable propositions. The last section concludes.

\section{FIRM-SPECIFIC INVESTMENTS AND THE NEED FOR INSTITUTIONAL SAFEGUARDS}

Market transactions create high transaction costs if either the buyer or the seller must make specific investments that generate quasi-rents (Williamson, 1985). As writing complete, contingent contracts on how the quasi-rents are divided is impossible, market relationships tend to be plagued by opportunistic behavior and underinvestment. Therefore, Williamson (1985) argues that relation-specific transactions should be organized within a hierarchy. The transaction-cost-based arguments in favor of an integration of relation-specific transactions remain vague as to the benefits of organizing transactions "within the firm" rather than "over the market." The seminal works of Grossmann and Hart (1986), Hart and Moore (1990), and Rajan and Zingales (1998a) show that, given asset specificity, integration per se does not remove the incentives for opportunistic behavior. Instead, the distribution of residual rights of control crucially affects the incentives for making firm-specific investments. If the shareholders have residual control, they could appropriate all quasi-rents. Consequently, the employees will be more reluctant to invest in firm-specific knowledge. If the employees with firm-specific knowledge have residual control, finding external financiers will be difficult. By determining the ownership structure of a firm, corporate governance plays a crucial role in balancing the conflicting interests of different firm-specific investors. 
In the last two decades the corporate governance literature has developed from a simple finance perspective, assuming that only shareholders need institutional protection by corporate governance mechanisms, to a more complex instrumental stakeholder perspective according to which the interests of multiple parties with firm-specific investments need to be protected.

Until the late-nineties the finance model dominated the corporate governance literature (Shleifer and Vishny, 1997): Shareholders provide capital to buy assets, such as factory buildings and production machines. Parts of the costs of these assets are sunk, so that the resale value is lower than the return from using the assets within the firm. The shareholders hold residual claims as they receive the returns after all contractual liabilities have been fulfilled. Shareholders of public corporations are ideal risk bearers, because stock markets enable them to diversify their risk across many corporations and to individually choose the extent to which they want to bear the risk of one particular firm (Fama and Jensen, 1983a). The assumption that only one group of residual claimants exists, the shareholders, provides the economic rationale for running the corporation in their interest. In this sense, maximizing shareholder value is the same as maximizing the total value creation. Therefore, the fundamental issue in corporate governance is to ensure that the quasi-rents generated by the firm-specific physical assets is prized out of the hands of managers and given to the shareholders (Jensen and Meckling, 1976; Shleifer and Vishny, 1997; Rajan and Zingales, 1998b).

In the $1980 \mathrm{~s}$ and $1990 \mathrm{~s}$, the importance of human capital relative to physical assets increased (Machin and Van Reenen, 1998) so that now firm-specific assets also, or even primarily, concern the specific human capital of the employees (Rajan and Zingales, 1998b). Specific human capital refers to knowledge, capabilities, and skills that are useful only to a single employer, whereas general human capital (such as literacy) is useful to several firms (Becker, 1964). More recent models of corporate governance (e.g., Blair, 1995; Zingales, 1998; Blair, 2000; Zingales, 2000; Luh Lan and Heracleous, 2010) accommodate the rising importance of firm-specific knowledge for production and admit that in addition to shareholders, stakeholders with firm-specific investments-most notably employees with firm-specific human capital—need institutional protection. Blair (1995) argues that employees with firm-specific knowledge are, indeed, residual claimants, just as shareholders are. Promised wage increases as a result of firm-specific knowledge investments are contingent on the performance of the firm. While in good years knowledge workers with firm-specific knowledge benefit by receiving wage premiums, in bad years they receive no 
wage premiums. In addition to the business risk, employees with firm-specific knowledge are also vulnerable to shareholders' opportunism, as the employers may not even share the profits in good years. To prevent this hold-up risk, the employees may refuse to make firm-specific investments on which the firm's competitiveness depends.

If only one residual claimant exists, the solution to the incentive issue of specific investments is to pair residual control and residual returns (Milgrom and Roberts, 1992, p. 291). If the production requires firm-specific physical assets but general human capital, shareholder-controlled firms emerge. Conversely, labor-controlled firms emerge if production requires specific human capital but general physical capital (Dow, 1993; Dow and Putterman, 2000). The solution, however, is more difficult to achieve if multiple persons with heterogeneous interests have residual claims. Because objectively attributing any particular portion of a firm's output to any particular contribution is impossible, serious problems may emerge in deciding how the quasi-rents should be divided (Blair and Stout, 1999). Given the superordinate objective of maximizing the joint product of the firm, it is the task of corporate governance to establish a set of institutions that are effective in balancing the competing interests of heterogeneous risk bearers. As the next section will show, tying residual rights of control to the residual claimants as a group is not the only approach to handling this problem.

\section{TWO OWNERSHIP MODELS TO INCENTIVIZE FIRM-SPECIFIC INVESTMENTS}

This section discusses two corporate governance models to setting up institutional safeguards for the returns to firm-specific investments: the shared ownership model and the third-party ownership model. The shared ownership model allocates the residual rights of control to the residual claimants, e.g., individuals with firm-specific assets. The third-party ownership model allocates residual rights of control to independent fiduciaries who have no residual claims because they have no firm-specific assets. To simplify matters, this paper concentrates on public corporations, and presumes that the corporation's competitive advantage is based on the mutually specialized contributions of shareholders and employees.

\section{Shared Ownership and Firm-Specific Investors as Directors}

In most legal contexts, the residual rights of control over a corporation are largely assigned to the board. The board has the power to set dividends, to hire and fire the top executives, and to determine the compensation system (Milgrom and Roberts, 1992). Thus the 
composition and constitution of the board is crucial for protecting the residual returns to firmspecific investments. The shared ownership model postulates that all residual claimants can elect representatives as directors. Blair (1995, p. 322) recommends that the firm should "enhance the voice of and provide ownership-like incentives to those participants in the firm who contribute or control critical, specialized inputs". Individuals who have no "exit" option should receive "voice," using Hirschman's (1970) terms, because "voice" provides some assurance to the specific investors that the board will consider their interests in the decisionmaking process. Both shareholders and employees with firm-specific skills jointly execute the residual rights of control and have a say in how quasi-rents are distributed. By reducing the danger of being exploited when becoming locked in to the firm, shared ownership increases the incentives to make firm-specific investments (Furubotn, 1988; Blair, 1995; 1996; Franck, 2002; Osterloh and Frey, 2006).

\section{Third-Party Ownership and Trustees as Directors}

An alternative model for protecting the returns to firm-specific investments is installing a trustee board. The third-party ownership model of corporate governance allocates the residual rights of control to independent directors who have no firm-specific assets (Rajan and Zingales, 1998a; Blair and Stout, 1999; 2001, Stout, 2003). Neutral trustees decide which party receives what share of the firm's quasi-rents generated. Ideally, the independent board makes these decisions with an eye towards maximization of the firm's quasi-rents. Thus to provide sufficient incentives for choosing an optimal level of firm-specific investments in the first place, the board ensures that large enough shares of the quasi-rents go to the stakeholders with firm-specific assets (Blair and Stout, 2001). Concerns for their reputations motivate outside directors to do their best to act as independent trustees, because a high reputation as an expert in decision control is helpful for those applying for future board memberships. As Fama and Jensen (1983b, p. 315) write:

[O]utside directors have incentives to develop reputations as experts in decision control (...) They use their directorships to signal to internal and external markets for decision agents that they are experts.

To credibly play the mediating role, the board itself must not be involved in firmspecific investments, and therefore must consist of outside directors who neither work for the firm nor hold shares. In addition, the board should not be entitled to any kind of "performance incentives" such as stock options. Any performance incentives would introduce conflicts of interest that impede impartial decision-making (Blair and Stout, 2001). 
Blair and Stout $(1999,2001)$ argue that the legal conception of the board for corporations in the U.S. and many other countries resembles the third-party ownership model. Even though the shareholder assembly elects the board, the directors have no obligation to follow the shareholder's wishes but instead act as fiduciaries for the firm itself. Corporate law fundamentally restricts the control rights of the shareholders in the general assembly. Their main job is to choose the members of the board. Blair and Stout (1999, p. 310) therefore argue that "shareholders' voting rights - at least in publicly traded corporations - are so weak as to be virtually meaningless."

The directors enjoy high autonomy, especially if no single shareholder or group of shareholders owns a controlling block of shares. Publicly held corporations are typically characterized by a widely dispersed share ownership, as risk bearers tend to spread their investments across many firms (Fama, 1980). Dispersed stock ownership facilitates thirdparty ownership for the following two reasons: First, to exercise their rights is inefficient for individual shareholders who hold small fractions of the company's stock. Second, a collective action or free-riding problem exists. All shareholders may benefit from a single shareholder's activism whether they contribute to the activist's costs or not. Thus shareholders in public corporations are considered "rationally apathetic" (Clark, 1986).

The high autonomy of the board is essential for it to credibly act as fiduciary. As high board autonomy requires dispersed stock ownership, the stock ownership concentration affects the choice of the governance structure. In regulatory environments where law does not enforce codetermination and therefore compulsory employee representation on the board, non-representation of shareholders through dispersion of shares is a facilitator of third-party ownership. The study of Setia-Atmaja (2009), for example, provides Australian evidence that the dispersion of stock ownership increases the number of independent directors defined as "individuals whose only business relationship to the firm is their directorship" (p. 698). We therefore hypothesize:

Proposition 1: The more concentrated the stock ownership of a firm, the more likely the firm chooses the shared ownership model over the third-party ownership model, ceteris paribus. 


\section{COMPARISON BETWEEN SHARED OWNERSHIP AND THIRD-PARTY OWNERSHIP}

Whereas the shared ownership model suggests tying together residual returns and residual control, the third-party ownership model suggests delegating the residual control to an independent fiduciary board. Neither model is generally better than the other: both have advantages and disadvantages, and the firm-specific context needs consideration when a firm determines the governance structure. We first discuss the empirical literature that analyzes the effect of employee representation on the board. We then analyze the contingencies that influence the preferability of one model over the other.

\section{Empirical Studies on Employee Representation on the Board of Directors}

In an ideal empirical study, we would randomly assign one of the two corporate governance structures to a similar pool of corporations and compare the influence on the firms' subsequent quasi-rents. However, the barriers to performing such experiments in the field are obvious. Even if some corporations would be willing to participate in such an experiment, econometricians would still face the difficulty of how to measure the quasi-rents of a firm. Nonetheless, these difficulties notwithstanding, field evidence may still be informative for the pros and cons of particular governance structures.

Related empirical papers mostly concentrate on the influence of employee representation on the board on firm performance. Gorton and Schmid (2004) examine the implications of labor representation on supervisory boards in Germany. They find that when employees and shareholders have equal representation, corporations trade 31 percent lower and have higher payrolls compared to companies where employee representatives fill only one-third of the supervisory board seats. Gorton and Schmid (2004) conclude that labor representation is able to influence the board to make decisions favorable to workers. With respect to the effect on shareholder return, Faleye, Mehrotra, and Morck (2006) find similar results using a cross-sectional sample of publicly traded U.S. firms. Labor-controlled firms tend to have lower market capitalization, invest less in long-term assets, take fewer risks, and grow more slowly. Interestingly, employee ownership also decreases labor and total factor productivity. This finding may either reflect the employees using their "voice" to attain greater leisure or the lower value of the employees' firm-specific human capital due to reduced investments in complementary firm-specific physical capital. 
Guedri and Hollandts (2008) analyze the impact of employee ownership and board representation on the performance of French firms. While they find an inverted U-shaped relationship between employee ownership and accounting-based performance measures, they cannot replicate their finding when using a market-based performance measure. Fauver and Fuerst (2006) confirm that no simple linear relationship exists between labor "voice" and firm performance but that the potential benefits of labor representation on a corporate board depend on the industry. Using a German sample, they show that firms in industries that require intense coordination and information-sharing activities benefit from employee board representation, whereas the effect on the market capitalization is insignificant for firms in less knowledge-intensive industries.

The empirical results have to be interpreted with caution for two reasons. First, the studies compare firms with high employee participation with firms with low employee participation. However, a lack of employee participation on the board is not necessarily the same as a trustee board. Second, in most cases (e.g., Fauver and Fuerst, 2006; Guedri and Hollandts, 2008) the studies use only the shareholder return as the performance measure, ignoring the parts of the quasi-rents paid to the employees. All in all, the empirical results do not provide evidence for a one-size-fits-all effect of employee board representation. The following two sections will show that different contextual factors moderate the agency costs and the costs of collective decision-making, both of which, in turn, affect the comparative advantage of one model over the other.

\section{Costs of Collective Decision-Making}

Whenever ownership is shared among a group of individuals, a method for collective decision-making has to be devised. The process of aggregating the preferences of multiple persons involves substantial costs (Hansmann, 1988; Hansmann, 1996). We argue that the third-party ownership model involves lower costs of collective decision-making than the shared ownership model. If shareholders and employees with firm-specific skills jointly exercise residual control, pronounced politics, power struggles, and rent seeking must be expected. Being able to participate in the decision-making process at the board level does not eliminate mutual opportunism. The board members may still try to extract a larger fraction of the quasi-rents at the cost of the other party. Majority voting, for example, still allows the group holding the majority to hold-up the minority. If the shareholders are the majority in the board, they can decide to distribute the entire quasi-rents to shareholders via dividends. 
Third-party directors as trustees, themselves, are not residual claimants, and so lack any direct incentives to try to exploit firm-specific investors. The absence of conflicts of interests facilitates the decision-making process. Third-party control promotes firm-specific investments, precisely because it enables all specific investors to make binding commitments to refrain from strategically using the power of ownership to extract rents from one another (Blair and Stout, 1999; 2001; Stout, 2003). With reference to the costs of collective decisionmaking, Hansmann (1990, p. 1816) therefore concludes: "Firms managed for their workers, it appears, often perform better than firms managed by their workers." We hypothesize:

Proposition 2: Third-party ownership results in lower costs of collective decisionmaking than shared ownership, ceteris paribus.

The comparative advantage of the third-party ownership model is moderated by the heterogeneity of the residual claimants. If all firm-specific investments concern only physical assets financed by small and dispersed shareholders, the costs of collective decision-making are low. Small shareholders have homogeneous interests with respect to most corporate decisions, as they all essentially want to maximize the net present value of the future cash flows (Hansmann, 1988). However, if the shareholders have different investment portfolios, conflicts of interest and inter-shareholder opportunism may emerge. Imagine a blockholder who enters a derivatives contract with a brokerage firm that allows him to keep the votes attached to the stock, while at the same time hedging away the economic risk stemming from share price movements. This blockholder then uses his voting rights to urge the board to acquire another company at a significant premium over the market price. He does so because he happens to also hold a large block of the acquired company. The deal-which is based on a real example described by Stout (2007, p. 794) -is an outright inter-shareholder rent transfer.

While inter-shareholder opportunism is a relevant issue in practice, even more important conflicts of interests arise when parties who receive "voice" also have other transactional relationships with the firm, e.g., salaried employees (Hansmann, 1996). Whereas the shareholders of a modern corporation-i.e., widely diversified security holders-care only about shareholder value, employees gain utility from a broader spectrum that includes the fixed compensation, bonuses and fringe benefits, job satisfaction, or the firm's reputation. While the different objectives of the internal workers with firm-specific human capital and the shareholders are obvious, interests may even vary substantially within the group of employees. Unlike the small shareholders, employees do not have a single well-defined 
objective. Workers are likely to have different preferences according to age, gender, health, family situation, the particular plant they work in, and type of work (blue collar or white collar) (Hansmann, 1993). As diversity increases the costs of collective decision-making, we hypothesize:

Proposition 3: Diversity of the firm-specific investors increases the relative advantage of third-party ownership in decision-making costs, ceteris paribus.

Another factor influencing the heterogeneity of interest among the firm-specific investors - and therefore the comparative advantage of the third-party ownership model — is whether the corporation is a single-product firm or a multi-divisional firm (M-form). Singleproduct firms have one pool of co-specialized human and non-human assets, whereas the multi-divisional firms have different pools of co-specialized and interrelated human and nonhuman assets. Consequently, the interest heterogeneity among the firm-specific investors is higher, ceteris paribus, in multi-divisional firms than in single-product firms. Therefore, we hypothesize:

Proposition 4: Multi-divisional firms are more likely to have third party ownership than single-product firms, ceteris paribus.

\section{Agency Costs}

In most public corporations substantial control rights are delegated to professional managers. Managers play a special role, as managerial capabilities are predominantly general and transferable skills (Murphy and Zàbjonik, 2007). Therefore, the firm's quasi-rents do not depend on the contributions of the managers. Yet, the managers affect the quasi-rents by their actions and decisions, because employment contracts with managers are unable to anticipate all future contingencies. Parts of the residual control rights are inevitably delegated to the managers, so that the managers have some discretion to pursue their own interests rather than acting on behalf of the firm-specific investors.

We argue that managers have less discretion to follow their own hidden agenda in firms with shared ownership than in those with third-party ownership. Shared ownership implies that employees with firm-specific knowledge have representation on the board. Because employees have substantial information as a by-product of their employment, they are in a better position to monitor managers than shareholders or independent third parties 
(Hansmann, 1990). As insiders, employees are well acquainted with internal processes and therefore depend less on information provided by the managers. In addition, employees have not only the means but also the incentives to acquire information about the managers' effectiveness, as the employees (unlike the dispersed shareholders) have large personal stakes in the fortunes of the firm. Thus, insider representation on the board counterbalances the managerial dominance by introducing highly informed monitors who help to reduce managerial opportunism, e.g., excessive perks (Hansmann, 1990; 1993: Osterloh and Frey, 2006). We hypothesize:

Proposition 5: Shared ownership results in lower agency costs than third-party ownership, ceteris paribus.

Fauver and Fuerst (2006) show that firms in industries that require greater labor involvement, high coordination, and more specialized skill sets benefit from employee board representation, whereas employee board representation has no effect for firms in less knowledge-intensive industries. Osterloh and Frey (2006) provide two reasons for shared ownership being especially important in knowledge intensive firms: First, only insiders may be able to evaluate knowledge generation and transformation within the firm, as outsiders are rarely able to comprehend and assess the quality of the knowledge process. Second, information asymmetry between management and the board increases with the importance of knowledge for the production process. We hypothesize:

Proposition 6: The knowledge intensity of the firm's production process increases the relative monitoring advantage of shared ownership, ceteris paribus.

As previously mentioned, employee representatives equipped with detailed operationlevel information should improve the monitoring effectiveness of the board. The higher the free cash flow, the more important monitoring the management becomes. In his influential paper, Jensen (1986) notes that the agency conflict between the residual claimants and the management is particularly great when the firm generates substantial free cash flow. As free cash flow is cash in excess of what is necessary for funding the projects that maintain the firm's competitiveness, managers tend to invest the money in projects with private benefits, such as perks, but with low returns for the firm-specific investors. Substantial free cash flows typically appear in stable industries with low growth. In a dynamic environment, the 
managers are less likely to invest in projects with private benefits, because doing so would endanger the survival of the firm, whereas in low-growth industries the managers have greater discretion to pursue their own goals. Therefore, we hypothesize:

Proposition 7: A high industry growth rate decreases the relative monitoring advantage of shared ownership, ceteris paribus.

\section{COMPARISON OF THE TWO MODELS WITH GERMAN-STYLE CODETERMINATION}

The German-style codetermination has similarities with the shared ownership model. German workers are entitled by law to elect half the members of the supervisory board for all corporations with more than 2000 employees. However, unlike the shared ownership model, German codetermination is not contingent on the firm-specific skills and knowledge of the workforce. Interestingly, codetermination legislation was first applied to the coal and steel industries, and only later extended to large firms in general.

The benefit of mandated codetermination is a matter of controversy. Many economists, most notably, Jensen and Meckling (1979, p. 474) argue that the legal restriction reduces efficiency:

If codetermination is beneficial to both stockholders and labor, why do we need laws which force firms to engage in it? Surely, they would do so voluntarily. The fact that stockholders must be forced by law to accept codetermination is the best evidence we have that they are adversely affected by it.

In contrast, Fauver and Fuerst (2006) argue that competitive forces may not necessarily lead to efficient governance structures. If substantial frictions exist in the market, the first-best solution may be obtained only by coordination. The empirical results on German codetermination are contradictory as well. FitzRoy and Kraft (1994) and Gorton and Schmid (2004) find that codetermination decreases efficiency, while Fauver and Fuerst (2006) show that it increases efficiency, at least for firms in industries with a high need for coordination. Different levels of the firm's decision-making and agency costs may explain at least part of the inconsistency of the empirical results.

We previously argued that labor participation increases the costs of collective decisionmaking. Peculiarities to the German model help to reduce the potential threat of inefficient politics at the board level in two ways: First, a shareholder representative acts as the board 
chairman, who can cast the decisive vote in any deadlock between the shareholder and the employee representatives. Second, Germany has a dual board structure. Codetermination applies to the higher supervisory board that is not involved in the daily business of the firm. The particular decisions for which employees and shareholders are most likely to have conflicting interests take place not at the supervisory board level but at the industry level, through collective bargaining between the unions and the employers' associations, or in dealings between the management and the work councils (Hansmann, 1993).

An additional factor that needs consideration when analyzing German codetermination is the high concentration of large shareholders in the German stock market. Fauver and Fuerst (2006) show that in 53\% of their sample of 786 large and small German firms, the largest shareholders own at least $25 \%$ of the voting stock, and that more than every third firm, namely $39 \%$, have a controlling shareholder with more than $50 \%$ of the voting stock. Roe (1998) argues that this high shareholder concentration in the German stock market is a rational reaction to the codetermination law, because dispersed owners could not otherwise act as an effective counterweight to employee representation. In other words, applying the third-party ownership model to German firms would require not only abandoning the codetermination law but also having dispersed stockowners. Otherwise, the trustee board would not be independent of shareholder influence.

\section{CONCLUSION}

As sustainable competitive advantage is based on a unique combination of cospecialized inputs, providing incentives for firm-specific investments is a key task of good corporate governance. By defining the firm's ownership structure (i.e., the holders of residual rights of control), corporate governance shapes the ex post bargaining over the quasi-rents and therefore the ex ante incentives for firm-specific investments. We discuss two models for governing the residual rights of control: either firm-specific investors or their representatives jointly exercise the residual rights of control (the shared ownership model), or an independent third party acts as a trustee endowed with the residual rights of control for mediating the different interests of the firm-specific investors (the third-party ownership model). The managerial implications of the two models are totally different: Whereas the shared ownership model suggests that the board ought to be more accountable to the stakeholders with firm-specific assets, the third-party ownership model suggests that the board must be independent and thus not under the direct control of any firm-specific investor. 
This paper is the first to contrast the two models in varying contextual situations based on agency costs and costs of collective decision-making. Given previous empirical results and theoretical considerations we make the following propositions: shared ownership is better able to incentivize firm-specific investments than third-party ownership, ceteris paribus, (1) if stockholder ownership is concentrated, (2) if diversity among the workforce is low, (3) if the corporation is a single-product firm rather than a multi-divisional firm, (4) if the knowledge intensity of the production process is high, and (5) if the growth rate of the industry is low.

This paper adds two new insights to the discussion on employee codetermination (e.g., FitzRoy and Kraft, 1993; Gorton and Schmid, 2004; Fauver and Fuerst, 2006): First, employee representation is not beneficial per se, but rather only if the employees contribute to the firm's quasi-rents by their firm-specific knowledge. Second, employee representation is not the only governance solution for incentivizing the firm-specific (knowledge) investments. Independent third-party directors may protect the returns to firm-specific investments at lower costs under certain conditions, for example, when the knowledge workers have very diverse objectives.

\section{References}

Barney, Jay B. (1991). Firm Resources and Sustained Competitive Advantage. Journal of Management. 17, 99-120.

Becker, G. S. (1964). Human Capital. A Theoretical and Empirical Analysis with Special Reference to Education. Chicago: University of Chicago Press.

Blair, M. M. (1995). Ownership and Control, Washington D.C.

Blair, M. M. (1996). Wealth Creation and Wealth Sharing. The Brookings Institution.

Blair, M. M., Stout, Lynn A. (1999). A Team Production Theory of Corporate Law. Virginia Law Review, 85, 247-328.

Blair, M. M. (2000). Firm-Specific Human Capital and Theories of the Firm. In Blair and Roe (eds.). Employees and Corporate Governance, Brookings, 58-90.

Blair, M. M., Stout L., A. (2001). Corporate Accountability. Director Accountability and the Mediating Role of the Corporate Board. Washington University Law Quarterly, 79, 403447.

Clark, R. (1986). Corporate Law, Little, Brown.

Dow, G. K. (1993). Why Capital Hires Labor: A Bargaining Perspective. American Economic Review, 83, 118-134. 
Dow, G. K., Putterman, L. (2000). Why Capital Suppliers (Usually) Hire Workers: What we Know and What We Need to Know. Journal of Economic Behavior \& Organization, 43, 319-336.

Fama, E. (1980). Agency Problems and the Theory of the Firm. Journal of Political Economcy, 88, 288-307.

Fama, E., and Jensen, M. C. (1983a). Agency Problems and Residual Claims. Journal of Law and Economics, 26, 327-349.

Fama, E., and Jensen, M. C. (1983b). Separation of Ownership and Control. Journal of Law and Economics, 26, 301-325.

Fauer, L.; Fuerst, M. E. (2006). Does good corporate governance include employee representation? Evidence from German corporate boards. Journal of Financial Economics, 82, 673-710.

Faleye, O., Mehrotra, V., and Morck, R. (2006). When Labor Has a Voice in Corporate Governance. Journal of Financial and Quantitative Analysis, 41, 489-510.

FitzRoy, F. R., and Kraft, K. (1994). Economic Effects of Codetermination. Scandinavian Journal of Economics, 95, 365-375.

Franck, E. (2002). Zur Verantwortung des Verwaltungsrates aus ökonomischer Sicht [The Responsibility of the Board: An Economic Perspective]. Unternehmung, 56, 213-225

Furubotn, E. G. (1988). Codetermination and the Modern Theory of the Firm: A PropertyRights Analysis. Journal of Business, 61, 165-181.

Gorton, G., and Schmid, F. A. (2004). Capital, Labor, and the Firm: A Study of German Codetermination. Journal of European Economic Association, 2, 863-905.

Grossman, S. J., and Hart, O. D. (1986). The Costs and Benefits of Ownership: A Theory of Vertical and Lateral Integration. Journal of Political Economy, 94, 691-719.

Guedri, Z., and Hollandts, X. (2008). Beyond Dichotomy: The Curvilinear Impact of Employee Ownership on Firm Performance. Corporate Governance: An International Perspective, 16, 460-474.

Hansmann, H. (1988). Ownership of the Firm. Journal of Law, Economics, and Organization, 4, 267-303.

Hansmann, H. (1990). When Does Worker Ownership Work? ESOPs, Law Firms, Codetermination and Economic Democracy. The Yale Law Journal, 99, 1979-1826.

Hansmann, H. (1993). Worker Participation and Corporate Governance. University of Toronto Law Journal, 43, 589-606. 
Hansmann, H. (1996). The Ownership of Enterprise. Harvard University Press, Cambridge Massachusetts.

Hart, O., and Moore, J. (1990). Property Rights and the Nature of the Firm. Journal of Political Economy, 98, 1119-1158.

Hirschman, Albert O. (1970). Exit, Voice and Loyalty. Responses to Decline in Firms, Organizations, and States. Cambridge.

Jensen, M. C. (1986). Agency Costs of Free Cash Flow, Corporate Finance, and Takeover. American Economic Review, 76, 323-329.

Jensen, M., and Meckling, W. (1976). Theory of the Firm: Managerial Behavior, Agency Costs, and Ownership Structure. Journal of Financial Economics, 3, 305-360.

Jensen, M., and Meckling W. (1979). Rights and Production Functions: An Application to Labor managed Firms and Codetermination. Journal of Business, 52, 469-506.

Klein, B., Crawford, R. A., and Alchian, A. A. (1978). Vertical Integration, appropriable rents, and the competitive contracting process. Journal of Law and Economics, 21, 297326.

Luh Lan, L. and Heracleous, L. (2010). Rethinking Agency Theory: The View from Law. Academy of Management Review, 35, 294-314.

Maching, S., Van Reenen, J. (1998). Technology and Changes in Skill Structure: Evidence from Seven OECD countries. Quarterly Journal of Economics, 113, 1215-1244.

Milgrom, P., and Roberts, J. (1992). Economics, Organization, and Management. New Jersey: Prentice Hall.

Murphy, K. J., and Zàbojnik, J. (2004). CEO Pay and Appointments: A Market-Based Explanation for Recent Trends. American Economic Review, 94, 192-196.

Murphy, K. J., and Zàbojnik, J. (2007). Managerial Capital and the Market for CEOs. Working Paper, University of Southern California.

Osterloh, M., and Frey, B. S. (2006). Shareholders Should Welcome Knowledge Workers as Directors. Journal of Management and Governance, 10, 325-345.

Rajan, R. G., and Zingales, L. (1998a). Power in a Theory of the Firm. Quarterly Journal of Economics, 113, 387-432.

Rajan, R. G.; Zingales, L. (1998b). The Governance of the New Entreprise. Working paper. University of Chicago.

Roe, M. J. (1998). German Co-Determination and German Securities Markets. In: Hopt, K. J., Kanda, H., Roe, M. J., Wymeersch, E., Prigge, S. (Eds.): Comparative Corporate 
Governance, State of the Art and Emerging Research. Oxford University Press, Oxford, pp. 369-372.

Setia-Atmaja, L. Y. (2009). Governance Mechanisms and Firm Value: The Impact of Ownership Concentration and Dividends. Corporate Governance: An International Review, 17, 694-709.

Shleifer, A., and Vishny, R. W. (1997). A Survey of Corporate Governance. Journal of Finance, 52, 737-783.

Stout, L. (2003). The Shareholders as Ulysses: Some Empirical Evidence on Why Investors in Public Corporations Tolerate Board Governance. Working Paper, University of California.

Stout, L. (2007). The Mythical Benefits of Shareholder Control. Virginia Law Review, 93, 789-809.

Williamson, O. (1985). The Economic Institutions of Capitalism: Firms, Markets, Relational Contracting. New York: Free Press.

Zingales, L. (1998). Corporate Governance. In: P. Newman (ed.), The New Palgrave Dictionary of Economics and the Law. New York: Macmillan 1998.

Zingales, L. (2000). In Search of New Foundations. Journal of Finance, 55, 1623-1653. 